\title{
Institutionalization of transnationalizing political parties: the case of the Conservative People's Party of Estonia
}

\author{
Mari-Liis Jakobson ${ }^{1,2^{*}}$ (D) Tõnis Saarts ${ }^{2}$ and Leif Kalev ${ }^{2}$
}

\author{
* Correspondence: mari-liis \\ jakobson@tlu.ee \\ ${ }^{1}$ The Whitney and Betty MacMillan \\ Center for International and Area \\ Studies, Yale University, 34 Hillhouse \\ Avenue, New Haven, CT 06511, USA \\ ${ }^{2}$ School of Governance, Law and \\ Society, Tallinn University, Narva \\ mnt 25, 10120 Tallinn, Estonia
}

\begin{abstract}
While party institutionalization research has advanced notably in the recent years, the institutionalization of political parties that extend their organizations abroad (i.e. transnationalizing parties) has remained an academically uncharted territory. This article draws on party institutionalization literature and analyses the particularities of institutionalization in transnationalizing parties. The findings suggest that transnational institutionalization takes place simultaneously on multiple levels (local, national and transnational) and is distinctly interactive, placing crucial importance on the activities and responsiveness of both the central party organization as well as the extraterritorial branches. The internal dimensions of institutionalization can be notably affected by the territorially and temporally scattered nature of emigrant communities and by the sense of inclusion provided to the activists. The external dimensions of transnational institutionalization involve a wider variety of actors than institutionalization on the national level and can also be more challenging due to the more contingent socialization patterns and interest in politics of transnational migrants. Transnational institutionalization of political parties is relevant to the parties and their continuous electoral success, but also for transnational migrant communities and impact of their political participation.
\end{abstract}

Keywords: Transnational parties, Party institutionalization, Emigrant voting, Transnational politics

\section{Introduction}

As ever larger emigrant communities retain transnational ties with their homeland and a growing number of states facilitate extraterritorial voting (Lafleur, 2015; Turcu \& Urbatsch, 2015), an increasing number of political parties are tempted to seek support from voters living abroad (Kernalegenn \& van Haute, 2020). While there is already some consensus over how the features of the emigrant community or the institutional organization of elections affects external voter turnout (e.g. Burgess \& Tyburski, 2020; Chaudhary, 2018; Ciornei \& Østergaard-Nielsen, 2020; Hutcheson \& Arrighi, 2015), the research into the role of party organization has thus far remained rather exploratory. While there are some studies charting the ways how party organizations expand

(c) The Author(s). 2021 Open Access This article is licensed under a Creative Commons Attribution 4.0 International License, which permits use, sharing, adaptation, distribution and reproduction in any medium or format, as long as you give appropriate credit to the original author(s) and the source, provide a link to the Creative Commons licence, and indicate if changes were made. The images or other third party material in this article are included in the article's Creative Commons licence, unless indicated otherwise in a credit line to the material. If material is not included in the article's Creative Commons licence and your intended use is not permitted by statutory regulation or exceeds the permitted use, you will need to obtain permission directly from the copyright holder. To view a copy of this licence, visit http://creativecommons.org/licenses/by/4.0/. 
abroad (Gherghina \& Soare, 2020; Østergaard-Nielsen \& Ciornei, 2019) or campaign abroad (Paarlberg, 2019, 2020; Wilcock, 2018), this article aims to contribute an alternative approach to parties that engage external voters (henceforth, we call them transnationalizing parties), namely, from the perspective of party institutionalization.

Party institutionalization is the key feature behind the success and stability - or destabilization and demise - of political party organizations. Institutionalization is not just related to the technical features of a party organization, but also with the ideological stability and development of the party, the development of a stable supporter base or the position of the party in the broader party system (Randall \& Svåsand, 2002). Thus, the systematic analysis of institutionalization would give us an understanding of how transnationalizing parties solidify as complex organizations, but also how transnational democracies consolidate, how emigrants become de facto significant players in homeland politics and how transnational issues enter the political agenda.

While the theories on party institutionalization in the nation-state context have developed notably over the years, they do not account for the particularities of the transnational context. This paper aims to connect party institutionalization and transnational migrant politics research, by asking, what particularities need to be accounted for in the institutionalization process of transnationalizing parties.

As the main aim for this article is theorizing the thus far untheorized institutionalization of transnational party organizations, we employ a relatively widely used method in social sciences - theory building from a case. Here we predominately rely on the seminal article by Eisenhardt and Graebner (2007), which defines casestudy based theory building as 'a research strategy that involves using one or more cases to create theoretical constructs, propositions and/or midrange theory from casebased, empirical evidence' (p. 25). John Gerring (2012, p. 741) warns that descriptive inference could bring an innovation only if 'delineating a fundamentally novel empirical terrain, or by thoroughly revising our sense of an established terrain". That is what this article intends to do - studying party institutionalization on "a novel empirical terrain". The theory developed in this article corresponds to Abend's (2008) definition of Theory3, according to which theory is not only answers to the question 'what $\mathrm{x}$ causes $\mathrm{y}$ ?', but also contributions that offer "an original 'interpretation,' 'reading,' or 'way of making sense' of a certain slice of the empirical world." Thus we develop a descriptive, rather than a predictive model of transnational party institutionalization.

Theoretically, the article draws on party institutionalization literature, which is adapted, with the support of scholarship on migrant political participation, to suit analysing party institutionalization beyond the confines of the nation-state. Next, the model is applied to an empirical case, which allows to test the adapted theory as well as complement it with some observations about the enabling and restricting factors affecting transnational party institutionalization.

The case utilized in this paper is the Conservative People's Party of Estonia (Eesti Konservatiivne Rahvaerakond - EKRE) in Finland. EKRE was established in 2012 after the electorally marginalized People's Union of Estonia (Eestimaa Rahvaliit) merged with a nationalist NGO called the Estonian National Movement (Eesti Rahvuslik Liikumine). EKRE initiated its branch organization in Finland in late 2014 and in Sweden in 2019, and is planning on initiating branches also elsewhere (EKRE, 2019). 
The article utilizes the logic of theoretical sampling, where researchers choose cases that are "unusually revelatory, extreme exemplars, or [present] opportunities for unusual research access" (Eisenhardt \& Graebner, 2007, p. 27). EKRE is a somewhat unusual, but also revelatory case (and thus well suited for theory building), because it is a relatively new party which began transnationalizing in relatively early stages of institutionalization and the authors have had the chance of following the party's transnational institutionalization processes in its most constitutive phase. While EKRE inherited a domestic structure from the People's Union, it has put a significant emphasis on institutionalization processes in the past few years. Hence, it can be assumed that transnationalization has been inherent also in the institutionalization process of the party rather than just serving 'old wine in new bottles' or 'new wine in old bottles' (Gherghina \& Soare, 2020). Of course, EKRE is a populist radical right party, putting a lot of emphasis on ethnonationalist, anti-immigrant and anti-gay identity politics (Kasekamp et al., 2019). While identity-based parties are not most typical in the scene of transnationalizing parties, they can be seen as influential cases: according to Burgess and Tyburski (2020), identity-based partisanship can increase voter mobilization by $3 \%$ on average. Finally, EKRE is an electorally significant party, both nationally and transnationally. The 2019 elections were the second parliamentary election for EKRE, and it scored the third best result (17.9\% of the total vote), subsequently entering the governing coalition as a junior partner. Furthermore, it was by far the most popular party (almost $44 \%$ of the vote) among voters abroad who cast their votes at the embassies. It seems that the institutionalization processes have played a significant role in the party's electoral success, because in its first general election 4 years earlier the party only garnered under $11 \%$ of the votes cast at the embassies and $8 \%$ domestically.

However, in many ways, EKRE is also a typical case (Seawright \& Gerring 2008) for studying party institutionalization on a transnational level. First, the Estonian institutional context of external voting is rather typical: like in most countries in Europe, external voters are registered automatically and they vote in the district they have biographical links to (Hutcheson \& Arrighi, 2015). The levels of electoral turnout are also rather typical, as the share of voters from the entire emigrant population remains in single digits. Secondly, Finland is the main destination for Estonian emigration, where about half of the voters registered as residing permanently abroad live. Typically, main destination countries tend to be the ones where transnationalizing parties are most active (Østergaard-Nielsen \& Ciornei, 2019). Thirdly, while ideologically particular, EKRE has a rather typical mass party structure with an extensive and vibrant network of local party branches as well as strong central leadership, a feature considered relevant for electoral success abroad (Østergaard-Nielsen \& Ciornei, 2019).

As such, the case offers us a rather typical entry point in terms of context, but also some particularities which may reinforce the institutionalization process, making it an exemplary case for theory building.

The article is composed of five subchapters. After the introduction, the subchapters on party institutionalization and particularities of transnational migrant politics outline the premises of the theory of transnational party institutionalization. This is followed by a methods section and an empirical chapter providing a more detailed overview of the transnationalization process of the Finnish branch of EKRE. The article ends with a conclusions and discussion subchapter, which sums up the particularities and 
challenges of transnationalized party institutionalization and proposes possible agendas for future research on transnational institutionalization of parties.

\section{Institutionalization of political parties}

Samuel Huntington was one of the first scholars, who attempted to conceptualize "institutionalization" and extended it to political parties. He defined institutionalization as "the process by which organizations and procedures acquire value and stability" (Huntington, 1968, p. 12). Angelo Panebianco (1988) further elaborated the definition and saw party institutionalization as "the way the organization 'solidifies' (p. 49), which he elaborates as "a process by which followers develop an interest in the survival of a party independent of its current leadership ... a party becomes valuable in and of itself, and its goals become inseparable and indistinguishable from it"' (p. 53-55).

Whereas Panebianco and Huntington predominantly concentrated on the intra-party processes, Kenneth Janda brought in the "external" component. He defines an institutionalized party as "one that is reified in the public mind so that 'the party' exists as a social organization apart from its momentary leaders, and this organization demonstrates recurring patterns of behavior valued by those who identify with it" (Janda, 1980, p. 19).

Randall and Svåsand (2002) have proposed one of the most elaborate frameworks for analysing party institutionalization so far, in which they distinguish between internal and external institutionalization. In their approach, internal institutionalization comprises of two dimensions: (1) systemness - increasing scope, density and regularity (or routinization) of the interactions within party structures; and (2) value infusion - "the extent to which party actors and supporters acquire an identification with and commitment to the party which transcend more instrumental or self-interested incentives for involvement" (p. 13). They further include relevant dimensions of external institutionalization into their framework: (3) decisional autonomy - party's freedom from interference in determining its own policies and strategies, (4) reification - the extent to which party's existence is established in the public imagination, and being considered as an established institution towards which various political actors and voters adjust their behaviour and attitudes accordingly.

The subsequent authors have proposed to divide reification into two functionally different categories: (1) perceptual institutionalization (Harmel et al., 2018) and (2) roots in the society (Arter \& Kestilä-Kekkonen, 2014). Perceptual institutionalization indicates whether other parties take the party in question seriously and whether they perceive it as a competitor and/or potential ally. Roots in the society indicates that the party has a stable or stabilizing electoral support, and a distinctive body of core voters who vote primarily for the party (and not just the leader) (Arter \& Kestilä-Kekkonen, 2014).

While so far most research on party institutionalization has focused on the national level party organizations, party institutionalization can also be studied from a methodologically non-nationalist perspective, i.e. on the regional or local level (Harmel et al., 2018), or on the transnational scale, as demonstrated below. Thus one can see a clear gap in the previous literature and an opportunity to studying party institutionalization on "a novel empirical terrain" (Gerring, 2012). 


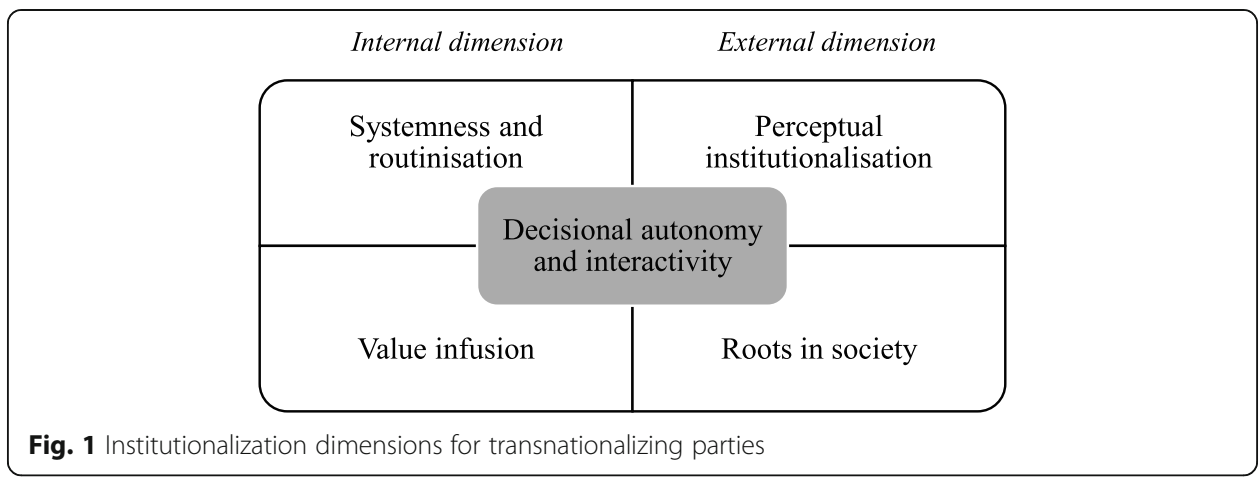

In this paper, we will address the institutionalization of transnationalizing parties, accounting for two internal and two external dimensions introduced in the overview above (see Fig. 1). In addition, we argue in this paper that understanding transnational level institutionalization requires a considerable degree of interactivity and some decisional autonomy both in the internal as well as the external dimension of institutionalization.

\section{Party institutionalization in the context of transnational migrant politics Decisional autonomy and interactivity}

In migration studies, the transnationalism paradigm brought into focus the fact that migrants are simultaneously both emigrants and immigrants and overturned the methodologically nationalist understanding of integration (Wimmer \& Glick Schiller, 2002). The notable popularity of the transnational approach across research areas (Vertovec, 2009) confirms the versatility of the concept, but also demonstrates that many nationstate centric concepts (e.g. political community, national identity) are often more complex.

The same applies to party politics. In national level party politics, the concept of 'decisional autonomy' of a party is of critical importance in order to determine whether the party is relevant as an independent entity (Randall \& Svåsand, 2002). When looking at party institutionalization in a multi-level context, however, autonomy becomes relevant also from a different aspect - as a relationship between the branch (es) and the central structure (Barberà \& Barrio, 2019). In the multi-level context, autonomy of the branch has to be in a delicate balance with interactivity, i.e. the branches need some autonomy in order to establish its particular identity and be able to assert the particular needs of their members, while also being cooperative with the central organization; and the central organization needs to be responsive to the branches. Finding this balance is often difficult and hence, parties can tilt towards one or the other extreme.

Similar trends also describe the external aspects of a transnational institutionalization context. The interactivity is inherent in the transnational experience, as migrants negotiate their belonging to their homeland, country of residence, the diaspora and translocal communities (Østergaard-Nielsen, 2003). In many ways, migrants are an autonomous group from the rest of the national community of fate, having particular political identities and interests. Yet, the identities and interests are subject to a constant transnational circulation (Boccagni et al., 2016), and the act of participating in 
homeland elections as a transnationalizing party and transnational citizens demonstrates both their interactivity with as well as autonomy from other organizations and arenas of participation.

\section{Systemness and routinization}

In a national context, systemness and routinization refers to either formal or informal rules, which become entrenched over time, and provide guidance for the actual behaviour within the party organization. A transnationalizing party organization complicates matters, as it typically consists of multiple important layers, e.g. the central party organization, normally run from the homeland, and external branch organizations sometimes housed under a more coordinated external caucus, as e.g. with the Democratic Party of the United States of America (von Koppenfels, 2020), but often not. Thus, the institutionalization of the transnationalizing parties is often a complex, interactive process requiring routines not just within and between the external branches, but also on the party's central level and vis à vis one another.

Transnational systemness and routinization can, in many ways, be even more challenging than on the national level. Parties' external branches are often run by activists with little linkages and coordination with the central party organization, and aiming to coordinate even simple things, e.g. similar Facebook page templates across external branches can thus be complicated (Gherghina \& Soare, 2020). The importance of interaction between homeland central organization and diaspora branches can be well illustrated by Paarlberg's (2019) comparative study of Salvadoran FLMN and ARENA parties, where the latter's ambitious billboard campaign failed due to the lack of coordination between the US branch and the domestic campaign organization. Even on the branch level, routinizing activities, e.g. the engagements with activists, organizing conventions etc. can be more challenging, as extraterritorial communities are often geographically rather dispersed (Faist, 2000) and thus more difficult to assemble.

\section{Value infusion}

Value infusion means the members' commitment to the party and identification with the party brand (rather than some charismatic individual) so that it transcends instrumental values. This can be a challenge for many parties setting out to campaign transnationally, even if they are well institutionalized on the national level. Abroad, the candidate selection processes can at times be rather instrumental, aiming to involve people who hold strategic positions in the community (e.g. are well known in the diaspora or work in positions where they have many personal contacts with the diaspora) rather than their alignment with the party's values (see e.g. Lafleur, 2013, p. 126), especially in special representation systems.

Transnational communities often also have particular interests and preferences different from domestic activists and voters (Palop-García, 2018), thus again underlining the necessity of interactivity and negotiation between the central party organization and that of the extraterritorial branches. The political preferences of the voters abroad can differ from those at home (see e.g. Turcu \& Urbatsch, 2020), suggesting either a divergent set of interests (Ciornei \& Østergaard-Nielsen, 2020) or effects of resocialization (Chaudhary, 2018). But in the longer view, emigrant communities tend to feature good 
pretences for remaining stakeholders in homeland politics (Bauböck, 2005) and thus, also extraterritorial branches can be subject to value infusion.

Thus, transnationalizing parties can either target a special representation strategy where they incorporate values and policy proposals important to the particular segment of emigrant voters and activists to their general political programme, or a voter maximization strategy, where the same political programme is expected to take both with emigrant as well as domestic voters and activists. The special representation strategy involves taking further obligations and potentially creating competition or contestation between various special interest groups within the party, which could end up damaging the coherence of the party. The voter maximization strategy, on the other hand, may create a weaker link with the external vote, especially if there is competition from other political parties.

\section{Perceptual institutionalization}

The perceptual institutionalization dimension demonstrates, to what extent a party is considered a 'lasting power' or an 'established party' by other parties and relevant political actors. In the transnational settings, the meaning of perceptual institutionalization could be even broader: transnational party institutionalization occurs, when not only the party itself, but also their transnationalization strategy is recognized and taken seriously by their potential allies and competitors both in the home country as well as the host country and/or on the international level (e.g. by the Europarties or other transnational party alliances, see e.g. Gómez-Reino, 2017), and those actors are ready to adjust their transnationalization strategies accordingly. Perceptual institutionalization can manifest in challenging the party, but also in surrendering, i.e. not putting extensive resources into a campaign where another party has an overwhelming advantage.

The perceptual institutionalization from the perspective of homeland parties can be notably affected by the overall low turnout of external voters (Hutcheson \& Arrighi, 2015). On the other hand, even if external votes make up a relatively modest proportion of the total vote, parties have motivation to maintain a close eye on what their competitors are doing abroad and calculate accordingly. External voters are to a great extent a self-selected group (Turcu \& Urbatsch, 2020) reacting to parties' mobilization attempts and in several cases, have also proved to be decisive. There are even cases (e.g. Mexico) where external voting is not allowed due to the incumbent party's perception of competitors' advantages abroad (Paarlberg, 2020). Also, in cases where the external vote is counted separately and later from the domestic vote (e.g. New Zealand), doing well with the expatriate vote can take on a symbolic importance for the parties (Gamlen 2015).

There are less studies conducted on the perceptual institutionalization of transnationalizing parties from the perspective of the country of residence parties, although there are some linkages between homeland elections and host country parties-ingovernment. For instance, the Salvadoran electoral campaigns in the US have been strongly influenced by the Republican presidents adopting a securitizing discourse against the left-wing FMLN party (and hence generating support for the right-wing ARENA party), while the Democratic administrations have contributed toward easing the confrontation (Paarlberg, 2019). 


\section{Roots in society}

In nation-state centric accounts of societal rootedness, two central indicators are presented: a stable supporter base and communicative links to the followers (Arter \& Kestilä-Kekkonen, 2014). In the territorially bounded nation-state context, the loyal followership of a party is easy to measure e.g. with public opinion polls. Abroad, such measures are more difficult to obtain. While expatriate electoral results are an important determinant of roots in society, turnout tends to be skewed towards more recent emigrants who are more highly educated and more interested in politics (Guarnizo et al. 2003; Chaudhary, 2018; Ciornei \& Østergaard-Nielsen, 2020; Finn, 2020). Alternative ways how to determine the extent of a transnationalizing party's roots in society can be determined e.g. by the ways how they campaign abroad. Here, a multiplicity of agents has been noted to play a role - e.g. emigrant civil society organizations (Feron, 2013; Lacomba 2016), but also government operated organizations, which sometimes may function as satellites of parties (Yener-Roderburg, 2020), family members back home (Córdova \& Hiskey, 2015; Paarlberg, 2020), as well as party organizations and campaigns (Østergaard-Nielsen \& Ciornei, 2019; Paarlberg, 2019, 2020), suggesting that transnationalizing parties' roots in society can often transcend the lines of sectors as well as state borders. Furthermore, different channels can be used to activate different identities in transnational supporters, e.g. by emphasizing their emigrant or diasporic identity, level of integration in the host country or national belonging to the homeland (Wilcock, 2018).

\section{Data and methods}

As typical to all theory-building exercises (Eisenhardt \& Graebner, 2007), the article utilizes multiple types and sources of data with emphasis on in-depth interviews. The in-depth elite interviews were conducted with key persons involved in the establishment and institutionalization of EKRE's branch in Finland (list of respondents in Annex 1). While the sample of respondents is small, they encompass all key actors involved in the process in 2014-2020, both at the central organizational level (the vicechairman of the party, who was also the key contact person for the Finnish branch) and the local level (all chairmen of the Finnish branch since its initiation, and other activists responsible for activities related to transnational institutionalization). The interviews were carried out between early 2018 and 2019. One respondent was interviewed twice due to change in position.

The interviews encompassed all four aspects of transnational institutionalization: the initiation and routinization of the branch and its various functions; value infusion with the focus on the activists' motivations of joining and taking responsibilities in the branch; the interactions and reactions of other organizations to analyse perceptual institutionalization; and target groups and campaign activities in order to assess roots in society. The interviewers also applied triangulation where appropriate (in addition to asking broadly similar questions, information obtained from one interview was also tested in the following interviews) and the interviews demonstrated good coherence, indicating sample saturation.

The interviews were complemented by secondary sources, studied both in advance and after the interviews. Systemness and routinization were studied based on the party statute and press releases; value infusion was analysed based on party leaders' public 
statements and party programme, party electoral lists and campaign materials; for the perceptual institutionalization analysis, the electoral manifestos and websites of other parties and the larger news outlets in Estonia and Finland were scanned for statements about EKRE's Finnish branch, and the election debate of all Estonian parties held in Helsinki in early 2019 was also analysed. The roots in society were analysed, based on the various social media channels the party branch uses (based on information obtained from the interviews).

\section{Institutionalization of EKRE as a transnationalizing party}

\section{Systemness and routinization}

Launching EKRE's branch in Finland was primarily a bottom-up initiative, but soon got recognized by the party leadership. Many of the initiators were already party members, but could not participate in the local organizations due to long distance. The issue got the attention of the central leadership in 2014 when around 20-30 persons residing in Finland became interested in joining and actively engaging with the party, but had difficulties with assigning themselves to a particular district organization, a requirement in the membership application.

The party's standard structure did not really favour establishing a subunit abroad as EKRE's regional structure follows the logic of electoral districts, but there is no electoral district for citizens abroad. As a result of the initiative by activists in Finland and the responsiveness of the party leadership, EKRE's council made a decision that the subunit in Finland is 'a branch that has the same rights as a district' and the party statute was amended so that it differentiates between districts that overlap with electoral districts and districts that do not (i.e. EKRE's branches in Finland and Sweden) (EKRE, 2016).

Branches abroad (districts not overlapping with electoral districts) can send their delegates to the party congress (EKRE, 2016, 9.2), but unlike districts overlapping with electoral districts, they cannot propose their own candidates for EKRE's list of candidates for elections (9.11). However, the central leadership of the party has the right to amend candidate lists, so they have included the chairmen of the branch in Finland into the list of candidates both in the 2015 and 2019 general elections.

The development of systems and routines at the extraterritorial branch level has taken time, as the branch leadership is relatively autonomous in local organizing, and thus relies a lot on the energy and talents of the chairman, the vice-chairmen and other members of the steering board, reflecting a notably early stage of institutionalization. The first leadership board elected in late 2014 remained relatively passive in organization building because of long distances (the first chairman lived hours away from Helsinki where most Estonians in Finland are based), lack of a supportive framework (no rooms for events, little organizational support as other Estonian organizations in Finland refused to cooperate with a political party), etc. However, the first chairman was active in the policy-making processes on the central party level and managed to include some clauses concerning the interests of Estonians residing abroad into the party's general programme and the electoral manifesto of 2015.

The branch leadership characterize the party's central office as quick and responsive over the phone and e-mail. The central organization provides the branch in Finland 
with 'moral support', sends central leadership delegates to their annual assemblies in Finland to motivate members abroad, helps them get their stories into party's central media channels and similarly to domestic branches, covers their expenses of up to 300 euros per month (2018). However, the first leadership never really used these resources, as due to lack of activity they did not have many running costs and unlike in some parts of Estonia, 300 euros is not enough to rent rooms in central Helsinki to host events.

The branch became more active 3 years later, in late 2017 when a new leadership was elected and began to organize and systematize the activities of the branch. The new chairman systematized the patchy documentation of the branch organization and aimed to boost up the processing of membership applications - the membership of the branch, which remained relatively stable from its initiation, has grown from around 40 members in spring 2018 to almost 100 members in spring 2019.

The branch leadership also gave a notable boost to the routinization of regular meetings, e.g. holding weekly leadership meetings and monthly pub or cafe meetings for members. In addition, the branch has aimed to establish new regular events in addition to the annual assembly - e.g. Independence Day ceremony, Mothers' Day celebrations, Midsummer Eve celebrations, a family festival in August, etc., though most of these plans had not realized by the end of 2019. The leadership members elected since 2017 all live in the Greater Helsinki area, thus meeting up and arranging events has become easier. However, since the membership is still scattered across the Greater Helsinki Area and for those living elsewhere in Finland, the attendance of broader audience events is very limited and the vast majority of members still only attend the annual assembly. Attendance is also restricted by the shifting working schedules, as many members are working for ten days in a row in order to get four days off (and travel to Estonia), or work different shifts in a $24 \mathrm{~h}$ cycle. Hence, it has been more productive to work with establishing membership activities online. The branch leadership holds its regular meetings online and in 2019, established a closed Facebook group for more engaged activists (in August 2019 it had 65 members). Even leadership holds its weekly meetings online (also prior to pandemic-related restrictions). Yet, the ambition of the party branch seems to be to build up a mass party type of organization with local subunits, and also initiate separate groups and activities, e.g. for women or families.

Until 2018, the branch representatives were modest participants in the central organization-building activities of the party. Since EKRE tends to hold its congresses away from the capital Tallinn and rather somewhere in central Estonia, it was difficult for the branch members to participate. However, in 2018, the branch recruited two new leadership members who are very active in attending all of the party's central events - in addition to the congress, also the party's torch marches, summer festival, etc.

\section{Value infusion}

The interviews suggest that EKRE follows the voter maximization described above, rather than the interest representation strategy. The central leadership of EKRE perceives that there is virtually no difference between the target group profiles at home and abroad. They have successfully managed to incorporate the target group abroad into 
the broader political narrative. EKRE has been primarily campaigning as a protest party, demonstrating that most of the problems in people's lives have been caused by the previous corrupt and inept governments. This includes emigration: EKRE depicts the Estonians in Finland as "economic deportees" who have been forced to leave their homeland because of the economic hardship, meagre social guarantees and chronic mismanagement by the previous neoliberal governments (EKRE, 2018). They also campaign for the return of Estonians residing abroad as a way to substitute for labour immigration from Ukraine, which is depicted as a threat to the Estonian society in general (Helme, 2019).

While branch activists admit that Estonians abroad have some particular interests and topics, they share the party's central perspective and rhetoric. Several respondents agreed that EKRE "is the only party that still recognizes us [Estonians abroad] as 'our own'”. However, several respondents also recall joining because of the party's other flagship issues, e.g. opposing the gender neutral partnership act and the refugee quotas in the framework of the European Agenda for Migration, thus abiding by the voter maximization strategy. The respondents perceive EKRE's values as quite compatible with those of Estonians abroad as, according to them, "Estonians living in Finland have an even fiercer anti-immigration attitude than Estonians living in Estonia, and precisely because they see it [life in a multicultural society] for themselves".

The success of value infusion is also reflected in the motivations the branch leadership members cite for joining the party and taking up voluntary work for the branch: they rather see EKRE as a social movement and value their role as enablers than regard the party as a career opportunity. Although the central leadership always includes candidates from extra-territorial branches into the electoral lists, Estonians currently in Finland are scattered across different homeland electoral districts, and thus, political career incentives are rather low. However, in 2020, then chairman of the Finnish branch became a central members' coordinator for the party, thus showing the potential of an internal career pathway.

\section{Perceptual institutionalization}

EKRE itself is clearly considered an 'established party' and 'lasting power' by other parties in the Estonian political system. The party was in the government coalition in 2019-2021, it has been recognized as an opponent by left-wing parties and affected the strategies of other parties on the right (Braghiroli \& Petsinis, 2019). Hence, - apart from the significant dependence on the charismatic leadership - the party has relatively good prospects for durability at the national level. Concerning the party's Finnish branch, it is more difficult to draw a similar conclusion. The other parties in Estonia are aware that EKRE has a party organization in Finland (e.g. EKRE's Finnish branch chairman represented the party at an election debate in Helsinki, while other parties sent their representatives from Estonia), but have not spoken out on the topic. So far, no other Estonian party has followed suit by establishing a branch in Finland. The only other party which has a branch abroad is the Social Democratic Party, which established a branch in Brussels already before 2014, but it has been rather inactive except in 2019, when it issued a few press releases. Estonian parties have occasionally campaigned in Finland - for instance, before the 2015 general election, the Reform party 
published its ads in Estonian diaspora newspapers, the Social Democrats purchased some billboard ads in Helsinki, and the Centre Party conducted campaigns by the Helsinki-Tallinn ferry terminal (ERR 2015). However, in 2019, the other parties remained more passive in their extraterritorial campaigns, although issues relevant for transnational Estonian communities appeared in the electoral manifestos of all major parties.

The reaction of the Finnish parties to EKRE's transnationalization has also been modest, but not absent. EKRE's Finnish branch has attempted to initiate cooperation with the True Finns, and proposed joint transnational campaigning: EKRE's activists in Finland campaigned for the True Finns in the Finnish 2017 local elections and hoped that the True Finns Party would endorse EKRE amongst the Finnish community in Estonia in the Estonian local elections. ${ }^{1}$ However, the True Finns were not very eager to develop tighter connections with EKRE's Finnish branch and rather preferred to seek contacts with EKRE's headquarters in Tallinn. EKRE's activists in Finland associated this with the True Finns having campaigned to send Estonian workers back home. (Please see Jakobson et al. (2020) for a more detailed discussion on why EKRE's activists accept that.) EKRE's Finnish branch members have more regular contacts with a True Finns' auxiliary organization, The Academic True Finns (HUPSA). The two have organized some activities and meetings together. EKRE and the True Finns regard one another as allies in the European Parliament, both being members of the new Identity and Democracy political group (Varjus, 2019).

The interviews indicated also a competitive attitude of EKRE's Finnish branch members towards the Finnish Social Democratic Party, which has been active in recruiting Estonians (and other immigrants) residing in Finland. Providing an alternative to becoming a member of the Finnish social democrats was actually cited as one of the reasons why EKRE's Finnish branch was founded in the first place. This demonstrates how transnational party activists can perceive host country national parties as "lasting powers" over their constituencies and strategize accordingly. However, there has been no indication, that the Finnish Social Democrats would regard EKRE in Finland as a competitor.

\section{Roots in society}

As earlier studies (Jakobson 2017; Jakobson et al. 2012) demonstrate, Estonians in Finland tend to be politically passive or even alienated. However, in the 2019 elections, the generally low voter turnout of Estonians in Finland changed dramatically and the embassy experienced long queues of voters, while polling stations in other countries did not (Lomp 2019). EKRE's activists in Finland associated the increase in turnout with their growing supporter base. This is at least partly supported also by numbers. While external voter turnout ${ }^{2}$ rose by $68 \%$ the support for most major parties remained the same, except for EKRE, who increased their share of votes almost seven fold (see Table 1). Isamaa (formerly IRL), another right-wing conservative party who lost almost

\footnotetext{
${ }^{1}$ About 4000 Finnish citizens in Estonia are eligible to vote. While to the authors' knowledge, the True Finns do not have extraterritorial branches, extraterritorial voters have gained significance in Finland, as the Finnish emigrants gained the right to vote by post in 2019.

${ }^{2}$ Here we only account for ballots cast on paper (i.e. at the embassy or by post), because the results of external voting are not differentiated from the rest of the online vote.
} 
Table 1 External voting results (postal voting and embassy voting combined) at 2015 and 2019 Estonian general elections

\begin{tabular}{lll}
\hline Votes per party & $\mathbf{2 0 1 5}$ & $\mathbf{2 0 1 9}$ \\
\hline -EKRE & $(132) 11 \%$ & $(921) 44 \%$ \\
-Reform Party & $(303) 25 \%$ & $(360) 17 \%$ \\
-Pro Patria & $(289) 23 \%$ & $(192) 9 \%$ \\
-Centre Party & $(180) 15 \%$ & $(200) 10 \%$ \\
-Social Democratic Party & $(189) 15 \%$ & $(211) 10 \%$ \\
-Others & $(140) 11 \%$ & $(194) 9 \%$ \\
-Total number of paper ballots cast abroad & 1251 & 2107 \\
\hline
\end{tabular}

Sources: Estonian Ministry of the Interior, Estonian Electoral Service

third of their votes over one election cycle, but party switching offers only partial explanation to EKRE's success. While it remains to be seen whether EKRE can consolidate such a high level of support, this is a strong indication that they have established channels through which to build roots in the transnational migrants' society.

EKRE's Finnish branch has been unable to build these roots via civil society organizations - partly due to the organizations' 'hostility' towards political parties and partly due to the overall weakness of the Estonian civil society in Finland. Several more prominent Estonian associations in Finland, are not classical diaspora organizations, but rather cultural associations that also cater for Estophile Finns. In 2019, however, a more constructive relationship was reported. For instance, the Tuglas Society, an NGO that promotes Estonian language and culture in Finland, hosted a pre-election debate in Helsinki, featuring all the political parties of Estonia.

Thus, the main channels EKRE uses to reach out to supporters abroad, are online. As many other radical right wing parties, EKRE has built up its own communicative ecosystem online, comprising of their own webzine Uued Uudised, the party website, an active social media page, and several Facebook groups. EKRE's Finnish branch has launched their own social media channels - the Facebook page of EKRE's branch in Finland (over 2200 followers in November 2019) is very active with several posts daily. There, the activists share their own thoughts on political issues, but equally often repost stories communicated by the party's central channels and stories from other likeminded channels.

In order to reach less engaged or informed supporters, the activists campaign both online as well as offline by distributing the party's printed newspaper in workplaces or by the ferry terminals, the main hubs for commuters between Estonia and Finland. EKRE's activists in Finland have also reached an agreement with the moderators of one of the largest Facebook group of Estonians in Finland with over 40,000 followers, where they are allowed to periodically post partisan content. During the election campaign period, they posted on average a couple of times per week (50 posts in the frame of 5 months were analysed), which include not only sharing EKRE's campaign materials (e.g. videos, visuals, comparisons with other parties), but also mobilizing posts (information about voting and appeals to vote for EKRE). Also, posts and polls on other topical political issues that align with EKRE's agenda were shared (e.g. on e-elections, the UN Global Compact on Migration, which EKRE opposes, but also expat pensions and returning to Estonia). Most of the posts generate a notable amount of discussion, but 
the mobilizing posts get by far most traction (up to 420 comments), which include both affirming as well as sceptical or even anti-EKRE comments.

\section{Discussion: towards a theory of transnational party institutionalization}

This article addressed the institutionalization among transnationalizing parties and proposed a framework of analysis (see Fig. 1). The article seeks to contribute to the research both on party institutionalization and political migrant transnationalism. In the former perspective, it enables us to move beyond methodological nationalism prevalent in studies on party institutionalization. In the latter, it provides a relatively comprehensive and systematic framework for exploring transnational parties and political organizing.

As the analysis above indicates, EKRE as a transnationalizing party is still in the process of becoming institutionalized in all four dimensions of institutionalization. However, the case study enables to define the dimensions of institutionalization of transnationalizing parties as well as chart the particularities and challenges of transnational institutionalization.

The case of EKRE exemplifies the importance of the interactivity-autonomy balances. A transnationalizing party requires much more than just a group of activists abroad, even in case transnationalization is initiated from the emigrant community. In terms of systemness and routinization, the central party organization had to amend their statute to facilitate extraterritorial branch organizations, open up its programme committees to suggestions from abroad, rethink networking opportunities for members in order to accommodate those abroad, and demonstrate support by sending its delegates to the branch assemblies. These examples also underline the extent to which party organizations tend to be founded on the closure of methodological nationalism. However, the local branch level also needs to reinvent party organizing in a situation where members are often dispersed over long distances, and in case of labour migrants, also along their shift schedules, thus benefitting from autonomy.

In terms of value infusion, the party's central level needs to figure out how to rhetorically include emigrants into their construction of 'the people' they aim to represent without at the same time, losing coherence for domestic members. As a populist party, EKRE found this in the need to defend the 'economic deportees' from the 'corrupt elites', but more moderately oriented parties can do the same with less antagonizing strategies. EKRE was also able to pursue the voter maximization strategy, which can also work for more moderate parties, but in terms of motivating transnational activists, the special representation strategy is definitely also worth considering. Since research into external voters' political preferences is still rather scant (exceptions include e.g. Turcu \& Urbatsch, 2020; Østergaard-Nielsen \& Ciornei, 2019), it is hard to determine whether there are any general trends which enable to forecast the success of either strategy.

However, value infusion also requires the local level to invent ways in which to make party membership meaningful and also in accordance with the party's overall style. In many transnationalizing parties, value infusion might be even more important than in domestic parties, as activists' incentives for joining are somewhat different. While EKRE is a radical party which induces the importance of its social movement like mobilization strategies, more centrist parties face the same challenges. Unless the electoral system 
grants special representation, the external votes tend to disperse between voting districts, making a political career for candidates abroad a lot harder to grasp. To bolster that, radical parties like EKRE (but also e.g. moderate En Marche! in France, see Kernalegenn \& Pellen, 2020) have their movement-like logic, other types of parties would need to find alternatives.

Transnational institutionalization has its particularities also in the external dimensions. Perceptual institutionalization takes place in relation to both the sending as well as the receiving countries' political parties and other organizations. The attention of previous studies has been primarily on the perceptual institutionalization within homeland politics, but this paper outlines also the particularities of perceptual institutionalization in host country politics. Immigrants can also be an important voter group and establishing alliances with immigrants' homeland parties can potentially be mutually beneficial, unless interest or value based conflicts emerge (as e.g. in case of EKRE and the True Finns). Furthermore, the analysis indicated that inter-party cooperation on a transnational and international level can be very different. However, the transnational field of perceptual institutionalization is also more diffuse and rather presents opportunities for mobilizing potential but thus far passive supporters, rather than compete for limited number of votes as in domestic politics.

Finally, transnational societal rootedness can be easily hampered by lower levels of political interest of the labour migrant community and territorial dispersion of the community, or the unwillingness of civil society organizations to become arenas for political campaigning. However, in times when all parties are investing more into their media and online visibility, building roots abroad can also become easier. Our study suggests that political parties may gain from looser editorial control online, and nonpartisan online news portals also enable migrants to remain part of the homeland public sphere. However, this of course does not mean that in many contexts, more traditional channels such as civil society organizations, family or diaspora networks or host country public sphere would not play an important role.

Thus far we have outlined numerous particularities of the transnational party institutionalization phenomenon. As transnational political participation contexts vary, the model presented in this article will hopefully be subject to future falsifying studies on parties from different party families, varying migratory contexts, etc., as customary in case based theories. However, the study also draws attention to new arenas requiring future systematic analysis. As mentioned, research on emigrants' political preferences is still scarce. Systematic analysis into the effects of the voter maximization and special representation strategies could also enable us explain how value infusion on a transnational level occurs. Furthermore, the transnational perceptual institutionalization process merits further investgation also from a multi-party perspective. And finally, while this study outlined some methods transnationalizing political parties might use in order to mobilize supporters, a larger-N comparison would give important insights into the relative success and reach of the various strategies.

All of this can contribute towards explaining the sustainability and functioning of transnational migratory spaces as spaces of political representation, and help to diagnose shortcomings in this field. In many ways, the model proposed in this paper is also a normative model that also enables practical stock-taking for parties on the ground. Hopefully, it also opens doors for descriptive studies focussed on levels of transnational 
institutionalization, and causal inference, which could explain why some parties have managed to institutionalize, while others remain relatively uninstitutionalized.

\section{Supplementary Information}

The online version contains supplementary material available at https://doi.org/10.1186/s40878-021-00241-5.

Additional file 1: Annex 1. Interview respondents.

\section{Acknowledgements}

The authors would like to thank Jean-Michel Lafleur for comments on an earlier version of this article and the suggestion to focus on party institutionalization; Emilie van Haute and Tudi Kernalegenn for their constructive comments, Karin Kuum for helping with carrying out interviews and transcribing them, and all of the interviewees for finding time and talking candidly. We are also extremely thankful to the two reviewers who made very constructive and insightful suggestions which helped the paper to achieve its current form.

\section{Authors' contributions}

All three authors participated substantially in all stages of preparing this article. TS outlined the preliminary theoretical framework on party institutionalisation, the case study design and wrote the first version of the institutionalization chapter, LK wrote the first version of the methods section and the systemness and routinisation chapter and carried out some of the interviews, MLJ wrote the first versions of the introduction, political transnationalisation, value infusion, roots in society and discussion chapter, carried out some of the interviews and streamlined and revised the article as a whole. All authors read and approved the manuscript.

\section{Funding}

This research was partly funded from the Juris Padegs Research Fellowship awarded by the Whitney and Betty MacMillan Center for International and Area Studies, Yale University, the European Union's Horizon 2020 research and innovation programme under grant agreement No 857366 and the DoraPlus programme, funded by the European Regional Development Fund and the Republic of Estonia.

\section{Availability of data and materials}

The interviews conducted and analysed during the current study are not publicly available due to respective agreement with the informants.

\section{Declarations}

\section{Competing interests}

The authors declare that they have no competing interests.

Received: 18 June 2020 Accepted: 8 April 2021

Published online: 12 August 2021

\section{References}

Abend, G. (2008). The meaning of 'theory'. Sociological Theory, 26(2), 173-199.

Arter, D., \& Kestilä-Kekkonen, E. (2014). Measuring the extent of party institutionalisation: the case of a populist entrepreneur party. West European Politics, 37(5), 932-956. https://doi.org/10.1080/01402382.2014.911486.

Barberà, O., \& Barrio, A. (2019). Podemos' and Ciudadanos' multi-level institutionalization challenges. Zeitschrift für Vergleichende Politikwissenschaft, 13(2), 249-272. https://doi.org/10.1007/s12286-019-00423-7.

Bauböck, R. (2005). Expansive citizenship: voting beyond territory and membership. PS: Political Science and Politics, 38(4), 683-687.

Boccagni, P., Lafleur, J. M., \& Levitt, P. (2016). Transnational politics as cultural circulation: Toward a conceptual understanding of migrant political participation on the move. Mobilities, 11(3), 444-463. https://doi.org/10.1080/17450101.2014.1000023.

Braghiroli, S., \& Petsinis, V. (2019). Between party-systems and identity-politics: the populist and radical right in Estonia and Latvia. European Politics and Society, 20(4), 431-449. https://doi.org/10.1080/23745118.2019.1569340.

Burgess, K., \& Tyburski, M. D. (2020). When parties go abroad: explaining patterns of extraterritorial voting. Electoral Studies, 66, 102169. https://doi.org/10.1016/j.electstud.2020.102169.

Chaudhary, A. R. (2018). Voting here and there: political integration and transnational political engagement among immigrants in Europe. Global Networks, 18(3), 437-460. https://doi.org/10.1111/glob.12171.

Ciornei, I., \& Østergaard-Nielsen, E. (2020). Transnational turnout. determinants of emigrant voting in home country elections. Political Geography, 78, 102145.

Córdova, A., \& Hiskey, J. (2015). Shaping politics at home: cross-border social ties and local-level political engagement. Comparative Political Studies, 48(11), 1454-1487. https://doi.org/10.1177/0010414015581683.

Eisenhardt, K. M., \& Graebner, M. E. (2007). Theory building from cases: opportunities and challenges. Academy of Management Journal, 50(1), 25-32. https://doi.org/10.5465/amj.2007.24160888.

EKRE (2016). EKRE Põhikiri [party statute], ratified 12.06.2016. https://www.ekre.ee/pohikiri/. Accessed 23 Aug 2019

EKRE (2018). Banner in Webzine Uued Uudised. https://uueduudised.ee/. Accessed 10 Feb 2018.

EKRE (2019, April 7). Stockholmis asutati EKRE Rootsi osakond [EKRE Swedish branch founded in Stockholm]. EKRE Homepage. https://ekre.ee/stockholmis-asutati-ekre-rootsi-osakond/. Accessed 25 Apr 2019. 
ERR (2015, February 17). Erakonnad teevad valimisreklaami üha enam ka välismaal elavatele eestlastele [Parties Campaign Increasingly Also Among Estonians Residing Abroad]. ERR News. www.err.ee/530031/erakonnad-teevad-valimisreklaa miuhaenam-ka-valismaal-elavatele-eestlastele.

Faist, T. (2000). The volume and dynamics of international migration and transnational social spaces. Clarendon Press. https:// doi.org/10.1093/acprof:oso/9780198293910.001.0001.

Feron, E. (2013). Diaspora politics: from 'long distance nationalism' to autonomisation. In D. Halm, \& Z. Sezgin (Eds.), Migration and organised civil society (pp. 76-91). Routledge.

Finn, V. (2020). Migrant voting: here, there, in both countries, or nowhere. Citizenship Studies, 24(6), 730-750. https://doi.org/1 $0.1080 / 13621025.2020 .1745154$

Gamlen, A. (2015). The impacts of extra-territorial voting: Swings, interregnums and feedback effects in New Zealand elections from 1914 to 2011. Political Geography, 44, 1-8.

Gerring, J. (2012). Mere description. British Journal of Political Science, 42(4), 721-746. https://doi.org/10.1017/S0007123412 000130.

Gherghina, S., \& Soare, S. (2020). Vote-seeking among non-resident citizens: how Romanian parties form organisations abroad. Representation, 1-17. https://doi.org/10.1080/00344893.2020.1815077.

Gómez-Reino, M. (2017). Nationalisms in the European Arena. Cham: Palgrave Macmillan.

Guarnizo, L. E., Portes, A., \& Haller, W. (2003). Assimilation and transnationalism: determinants of transnational political action among contemporary migrants. American Journal of Sociology, 108(6), 1211-1248.

Harmel, R., Svåsand, L. G., \& Mjelde, H. (2018). Institutionalisation (and De-institutionalisation) of right-wing protest parties: The Progress parties in Denmark and Norway. London: Rowman \& Littlefield, ECPR Press.

Helme, M. (2019, April 9). Majandus peab olema tark, mitte orjatööjõul põhinev [Economy has to be smart, not based on slave labour]. ERR News. https://www.err.ee/928411/mart-helme-majandus-peab-olema-tark-mitte-orjatoojoul-pohinev. Accessed 11 Nov 2019.

Huntington, S. P. (1968). Political order in changing societies. New Haven: Yale University Press.

Hutcheson, D. S., \& Arrighi, J. T. (2015). "Keeping Pandora's (ballot) box half-shut": a comparative inquiry into the institutional limits of external voting in EU member states. Democratization, 22(5), 884-905. https://doi.org/10.1080/13510347.2014. 979161.

Jakobson, M. L. (2017). 'It all does not matter that much in the European Union'-Migrant Transnationalism and the Transformation of Post-Communist Citizenship Discourse. Europe-Asia Studies, 69(5), 754-770.

Jakobson, M. L., Järvinen-Alenius, P., Pitkänen, P., Ruutsoo, R., Keski-Hirvelä, E., \& Kalev, L. (2012). The emergence of EstonianFinnish transnational space. In Migration and Transformation (pp. 159-205). Dordrecht: Springer.

Jakobson, M. L., Saarts, T., \& Kalev, L. (2020). Radical right across borders? The case of EKRE's Finnish branch. In T. Kernalegenn, E. van Haute (Eds.), Political Parties Abroad: A New Arena for Party Politics (pp. 22-37). London: Routledge.

Janda, K. (1980). Political parties: a cross-national survey. New York: Free Press; Collier Macmillan.

Kasekamp, A., Madisson, M.-L., \& Wierenga, L. (2019). Discursive opportunities for the Estonian populist radical right in a digital society. Problems of Post-Communism, 66(1), 47-58. https://doi.org/10.1080/10758216.2018.1445973.

Kernalegenn, T., \& Pellen, C. (2020). En Marche, French expatriates! The booming emergence of a new political actor among French residents overseas in the 2017 elections. In T. Kernalegenn, \& E. van Haute (Eds.), Political parties abroad: a new Arena for party politics (pp. 96-104). Abingdon: Routledge. https://doi.org/10.4324/9781003015086-8.

Kernalegenn, T., \& van Haute, E. (2020). Introduction. Why study political parties abroad? Diasporas as new arenas for party politics. In T. Kernalegenn, \& E. van Haute (Eds.), Political parties abroad. A new Arena for party politics (pp. 1-18). Abingdon: Routledge. https://doi.org/10.4324/9781003015086-1.

Lacomba, C. (2016). Mobilising abroad across ethnic lines: Home-country politics and immigrant political engagement in comparative perspective. Ethnicities, 16(1), 86-110.

Lafleur, J. M. (2013). Transnational politics and the state: the external voting rights of diasporas. London: Routledge. https://doi. org/10.4324/9780203077283.

Lafleur, J.-M. (2015). The enfranchisement of citizens abroad: variations and explanations. Democratization, 22(5), 840-860. https://doi.org/10.1080/13510347.2014.979163.

Lomp, L-E. (2019, February 17). Fotod: Helsingis tekkis hääletajatest saatkonna ukse taha mitmetunnine järjekord [Photos: Voters queues for several hours behind Helsinki embassy doors]. Postimees. https://www.postimees.ee/6525403/fotodhelsingis-tekkishaaletajatest-saatkonna-ukse-taha-mitmetunnine-jarjekord. Accessed 21 Apr 2021.

Østergaard-Nielsen, E. (2003). The politics of migrants' transnational political practices. International Migration Review, 37(3), 760-786. https://doi.org/10.1111/j.1747-7379.2003.tb00157.x.

Østergaard-Nielsen, E., \& Ciornei, I. (2019). Political parties and the transnational mobilisation of the emigrant vote. West European Politics, 42(3), 618-644. https://doi.org/10.1080/01402382.2018.1528105.

Paarlberg (2020). Anti-party skew and variation in diaspora outreach by Mexican parties. In T. Kernalegenn, \& E. van Haute (Eds.), Political parties abroad: a new Arena for party politics (pp. 218-237). Abingdon: Routledge. https://doi.org/10.4324/ 9781003015086-5.

Paarlberg, M. A. (2019). Competing for the diaspora's influence at home: party structure and transnational campaign activity in El Salvador. Journal of Ethnic and Migration Studies, 45(4), 539-560. https://doi.org/10.1080/1369183X.2017.1409166.

Palop-García, P. (2018). Contained or represented? The varied consequences of reserved seats for emigrants in the legislatures of Ecuador and Colombia. Comparative Migration Studies, 6(1), 1-20.

Panebianco, A. (1988). Political parties: organisation and power. Cambridge: Cambridge University Press.

Randall, V., \& Svåsand, L. (2002). Party institutionalisation in new democracies. Party Politics, 8(1), 5-29. https://doi.org/10.11 $77 / 1354068802008001001$.

Seawright, J., \& Gerring, J. (2008). Case selection techniques in case study research: A menu of qualitative and quantitative options. Political Research Quarterly, 61(2), 294-308.

Turcu, A., \& Urbatsch, R. (2015). Diffusion of diaspora enfranchisement norms: A multinational study. Comparative Political Studies, 48(4), 407-437. https://doi.org/10.1177/0010414014546331.

Turcu, A., \& Urbatsch, R. (2020). European ruling parties' electoral strategies and overseas enfranchisement policies. European Journal of Political Research, 59(2), 269-289. https://doi.org/10.1111/1475-6765.12357. 
Varjus, S. (2019, April 18). Halla-aho haluaa kimppaan Viron Ekren kanssa - Euroopan populistit kuhertelevat [Halla-aho wants an Alliance with Estonia's EKRE - European populists bill and coo]. I/ta-Sanomat. https://www.is.fi/politiikka/art-2 000006077120.html. Accessed 11 Nov 2019.

Vertovec, S. (2009). Transnationalism. London: Routledge. https://doi.org/10.4324/9780203927083.

von Koppenfels, A. K. (2020). Federal structure and party politics as simultaneous opportunity and constraint: Transnational political engagement of overseas Americans. In T. Kernalegenn, \& E. van Haute (Eds.), Political parties abroad. A new Arena for party politics (pp. 39-56). Abingdon: Routledge. https://doi.org/10.4324/9781003015086-4.

Wilcock, C. (2018). Mobilising towards and imagining homelands: diaspora formation among UK Sudanese. Journal of Ethnic and Migration Studies, 44(3), 363-381. https://doi.org/10.1080/1369183X.2017.1313104.

Wimmer, A., \& Glick Schiller, N. (2002). Methodological nationalism and beyond: nation-state building, migration and the social sciences. Global Networks, 2(4), 301-334. https://doi.org/10.1111/1471-0374.00043.

Yener-Roderburg, I. Ö. (2020). Party organizations across borders: top-down satellites and bottom-up alliances. The case of AKP and HDP in Germany. In T. Kernalegenn, \& E. van Haute (Eds.), Political parties abroad: a new arena for party politics (pp. 218-237). London: Routledge.

\section{Publisher's Note}

Springer Nature remains neutral with regard to jurisdictional claims in published maps and institutional affiliations.

Submit your manuscript to a SpringerOpen ${ }^{\circ}$ journal and benefit from:

- Convenient online submission

Rigorous peer review

- Open access: articles freely available online

- High visibility within the field

- Retaining the copyright to your article

Submit your next manuscript at $\boldsymbol{\nabla}$ springeropen.com 